\title{
PERSPECTIVA
}

REVISTA DO CENTRO DE CIÊNCIAS DA EDUCAÇÃO

Volume 38, n. 2 - p. 01 - 25, abr.jun. 2020 - Florianópolis

Fausto Delphino Scote

Universidade Federal de São Carlos, UFSCar

E-mail: faustoscott@gmail.com

(1) https://orcid.org/0000-0003-0541-6892

Marcos Roberto Vieira Garcia

Universidade Federal de São Carlos, UFSCar

E-mail: mgarcia@ufscar.br

(1) http://orcid.org/0000-0002-5668-2923

\section{Trans-formando a universidade: um estudo sobre o acesso e a permanência de pessoas Trans no Ensino Superior}

\section{Fausto Delphino Scote Marcos Roberto Vieira Garcia}

\section{Resumo}

O presente artigo trata do acesso e da permanência da população trans junto ao ensino superior. Paralelamente a uma revisão bibliográfica concernente ao tema, é apresentada uma pesquisa de campo composta por seis entrevistas abertas com mulheres trans e travestis e uma entrevista com um homem trans. Os sujeitos abordados pertencem a diferentes raças/etnias, classes sociais e frequentam diferentes universidades. Os resultados apontam que o acesso à universidade foi facilitado por conquistas específicas do movimento trans - como a implementação legal e o direito de utilização do nome social para travestis e transexuais em instituições de ensino que aderiram à legislação e nas avaliações nacionais como o ENEM - e por conquistas mais amplas, destacadas as políticas governamentais voltadas ao acesso de minorias étnicas e raciais de baixa renda, via oferta de vagas em universidades públicas federais e estaduais pelo sistema SISU, e oferta de bolsas de estudos em universidades privadas e confessionais, pelo PROUNI. Também foi fundamental o recurso de projetos sociais, como o "cursinho preparatório", voltados a travestis e transexuais. Por outro lado, ainda são isolados os casos de políticas públicas de permanência relacionadas à população trans, inexistindo oferta e manutenção de políticas públicas específicas. Foram relatadas dificuldades relativas ao pagamento de matrícula e mensalidades da universidade; à utilização de banheiro segundo o gênero de identificação; ao acesso à moradia estudantil e a bolsas de auxílio-alimentação; e a falta de trato adequado por parte de docentes e funcionárias/os não capacitadas/os a lidarem com pessoas trans. Desta forma, conclui-se que a participação na militância trans no contexto universitário constitui elemento importante para a transformação deste ambiente, contribuindo para a mudança de paradigmas; a aceitação das subjetividades; o reconhecimento de direitos; e o respeito à diversidade humana.

Palavras-chave: Travestilidades. Transexualidades. Universidade. 


\begin{abstract}
Keywords:

Travestilities.

Transsexualities. University.

Trans-forming the university: a study on access and permanence of trans people in higher education

This paper analyzes the access and permanence of the trans population in higher education. In addition to the bibliographic research, it is based on a field work that included six open interviews with travestis and transgender women and one with a transgender man of different races / ethnicities, social classes and types of university that they attend. The results show that access to university was facilitated by specific achievements of the trans movement - such as the legal implementation and the right to use the social name in institutions that adhered to legislation and national assessments such as ENEM - but was also facilitated by the government policies focused on low-income ethnic and racial minorities by offering vacancies in federal and state public universities through the SISU system and by offering scholarships in private and confessionals universities by PROUNI. The appeal of many to "preparatory course", aimed at travestis and transsexuals, was also fundamental. On the other hand, the public policies for transgender people regarding the permanence on the universities are very few. Difficulties related to the payment of university fees, the use of bathrooms according to gender identification, access to student housing and food aid, as well as the lack of training programs for teachers and other employees to deal with trans people, have been reported. Participation in trans militancy within the university context has become important for the transformation of the environment they inhabit, contributing to the change of paradigms, acceptance of their subjectivities, recognition of rights and respect for human diversity.
\end{abstract}

\section{Resumen}

Palabras clave:

Travestis.

Transexualidades. Universidad.

\section{Trans-formando la universidad: un estudio sobre el acceso y la permanencia de las personas trans en la educación superior}

El presente artículo tiene como objetivo analizar el acceso y la permanencia de la población trans en la enseñanza superior. Además de la investigación bibliográfica, se basa en un trabajo de campo que involucró la realización de seis entrevistas abiertas con mujeres trans y travestis y una con un hombre trans, de diferentes razas / etnias, clases sociales y tipos de universidad que frecuentan. Los resultados apuntan que el acceso a la universidad se ha facilitado por conquistas específicas del movimiento trans - como la aplicación legal y el derecho de utilización del nombre social para travestis y transexuales en instituciones de enseñanza que se adhirieron a la legislación y en las evaluaciones nacionales como ENEM - pero también por otras más amplias, entre las que destacan las políticas gubernamentales dirigidas a minorías étnicas y raciales de baja renta por el ofrecimiento de vacantes en universidades públicas federales y estatales por el sistema SISU y el ofrecimiento de becas de estudios en universidades privadas y confesionales por PROUNI. Fue fundamental también el recurso de muchas a proyectos sociales del tipo "curso de preparación", convertidos a travestis y transexuales. Por otro lado, todavía se aislan los casos de políticas públicas de permanencia cuando se relaciona a la población trans, sin la existencia de especificidad en el ofrecimiento y mantenimiento de políticas públicas que contribuyan para ello. Se relataron dificultades relacionadas al pago de subscripción y mensualidades de la universidad, a la utilización de cuarto de baño según el género de identificación, al acceso a la vivienda estudiantil y a las bolsas de auxilio-alimentación, además de la falta de tratamiento adecuado por parte de docentes y funcionarios/as no capacitados/as para lidiar con las personas trans. La participación en la militancia trans dentro del contexto universitario se presentó como importante para la transformación del ambiente que habitan, contribuyendo para el cambio de paradigmas, la aceptación de sus subjetividades, el reconocimiento de derechos y el respeto a la diversidad humana. 


\section{Introdução}

Este artigo trata das condições de acesso e permanência da população trans ${ }^{1}$ no ensino superior nas universidades públicas e/ou privadas no país, por meio da compreensão das estratégias que produzem para resistir aos preconceitos e discriminações acarretados por sua expressão de gênero no espaço universitário. Objetivou-se perceber os fatores que dificultam seu acesso e permanência na universidade e como são construídas as experiências de travestilidades e transexualidades, tendo em vista que a universidade ainda é, predominantemente, um locus cis-heterossexual.

Para um maior aprofundamento das informações, foram realizadas sete entrevistas abertas e presenciais, segundo a técnica de gravação de depoimentos orais (QUEIROZ, 1983). O trabalho envolveu os discursos de pessoas trans acerca de suas vivências universitárias, levando em consideração as seguintes especificidades: pessoas que se identificam como travestis, homens trans e/ou mulheres trans; pessoas que frequentam/frequentaram universidades públicas e privadas; pessoas que se identificam étnico-racialmente de forma diferenciada, pessoas de origem sócio-econômica distintas, pessoas que moram em capitais ou no interior.

Estão presentes nas discussões e análise dos dados diferentes correntes de pensamento, sobretudo a perspectiva pós-estruturalista, segundo a qual os saberes são construídos de modo interdisciplinar, dialogando com outras abordagens científicas como a filosofia, a psicologia social, a antropologia e as outras ciências sociais em geral.

O pensamento pós estruturalista desenvolveu uma série de diferentes métodos e abordagens como
por exemplo, a arqueologia, a genealogia, a desconstrução, cada um dos quais funciona de acordo
com sua própria lógica, mas, considerados em seu conjunto, eles tendem a enfatizar as noções de
diferença, de determinação local, de rupturas ou descontinuidades históricas, de seriação, de
repetição e uma crítica que se baseia na ideia de "desmantelamento" ou de "desmontagem" (leia-se
"desconstrução") (PETERS, 2000, p. 37).

A constituição dos sujeitos dentro do viés pós-estruturalista e em conformidade com os estudos queer $^{2}$ desdobram-se na noção de identidade. Segundo PETERS (2000), o sujeito pós estruturalista pode ser “[...] notado como maleável e flexível, estando submetido às práticas e estratégias de normatização e individualização que caracterizam as instituições modernas” (p.33). E, pela perspectiva queer, a hegemonia heteronormativa pode ser objeto de concepção mais crítica. Ou seja, a sociedade, ou a cultura, como nós as conhecemos, pelas teorias sociais instituídas, demarcam os limites do pensável: "O ‘impensável' está assim plenamente dentro da cultura, mas é plenamente excluído da cultura dominante”. (BUTLER, 2012, p.117).

Segundo MISKOLCI (2009), os teóricos queer analisam os discursos produtores de saberes sexuais através de métodos desconstrutivistas, não priorizando estudos empíricos a propósito dos comportamentos sexuais que levem à sua classificação, ou compreensão. Parte-se, portanto, de uma descrença com relação à estabilidade dos sujeitos sexuais, colocando em xeque os processos sociais 
classificatórios e hierarquizadores dos comportamentos buscando, assim, revelar um olhar com mais afinco para estes processos, que geram a ilusão de sujeitos estáveis e identidades sociais e comportamentos coesos e aceitáveis.

$\mathrm{O}$ interesse queer por travestis, transexuais e pessoas intersex se deve ao compromisso científico de crítica dos apanágios identitários e concepções de sujeitos unitários e estáveis. A Teoria Queer busca romper as lógicas binárias que resultam no estabelecimento de hierarquias e subalternizações, mas não apela à crença humanista, ainda que bem-intencionada, nem na "defesa" de sujeitos estigmatizados, pois isto congelaria lugares enunciatórios como subversivos e ignoraria o caráter contingente da agência. A crítica da normalização aposta na multiplicação das diferenças que podem subverter os discursos totalizantes, hegemônicos ou autoritários. (MISKOLCI, 2009, p. 175).

A teoria queer, por esse viés analítico, contribui para a compreensão de que não só as populações trans constroem suas identidades performaticamente a partir de suas expressões de gênero, mas também que todas as categorias humanas de existência se encontram produzidas e impostas pelas práticas reguladoras da coerência do gênero. Por isso, há a necessidade de uma observação diferenciada, de narrativas que abarquem toda essa fluidez na composição e na performatividade dos corpos.

Dessa forma, narrativas queer podem permitir pensar as ambiguidades e a fluidez das identidades
de gênero e orientações sexuais. Elas podem sugerir novas formas de pensar a cultura, o
conhecimento e o poder de forma que as diferenças não sejam apreciadas com curiosidade
exotificante. Narrativas queer estariam voltadas para a instabilidade das identidades e a diferença
alheia passa a ser vista ao lado, dentro e integrada nas redes do cotidiano. (GONÇALVES, 2015,
p. 12).

Embora recentemente alguns estudos tenham enfocado as consequências da transfobia ${ }^{3}$ no contexto escolar, ao realizarmos um levantamento mais aprofundado sobre as vivências de pessoas trans na universidade, encontramos somente discussões sobre os direitos dentro de uma perspectiva mais ampla, enfocando políticas públicas, projetos de lei e ações sociais visando ampliar a visibilidade social, política e econômica dessa população.

A aceitação, aplicação e legalização do uso do nome social é um dos elementos que colaboraram para a ampliação e, principalmente, o acesso da população trans ao Ensino Superior. Conforme dados do Instituto Nacional de Pesquisas Educacionais Anísio Teixeira (INEP), o número de travestis e transexuais que realizaram o Exame Nacional do Ensino Médio (ENEM) saltou de 102, em 2014, para 278, em 2015, e 408 em 2016, quadruplicando em um intervalo de 2 anos. (INEP, 2016).

Mesmo que programas governamentais voltados a segmentos mais amplos beneficiem também pessoas trans, é notória a ausência de programas específicos de acesso à universidade para essa população. Embora sejam previstas ações específicas neste sentido em documentos oficias e planos nacionais de políticas LGBT, foi encontrada apenas uma iniciativa por parte do poder público, nas três esferas relativas a este tema: o projeto Transcidadania. Este projeto, realizado pela prefeitura de São Paulo desde 2015, tem como foco a promoção de cidadania para pessoas trans por meio de políticas públicas de saúde, assistência social e acesso estudantil de formação profissional e acadêmica, oferecendo um salário e inclusão em programas assistencias. ${ }^{4}$ Há, ainda, iniciativas desenvolvidas por ONGs focadas 
à escolarização nos vários níveis, a grande maioria oferecendo cursinhos preparatórios específicos para travestis e transexuais para a realização do ENEM.

Há, também, carência de políticas específicas que garantam a permanência da população trans dentro das universidades ${ }^{5}$, pois sua escolarização é um direito muitas vezes negado - particularmente devido a limitações ocasionadas pelo sistema educacional - que ainda pode representar uma das únicas possibilidades de visibilidade, ascensão econômica, social e cultural para esse grupo.

Porém, a partir de 2014, os poucos avanços relacionados a políticas educacionais e de reconhecimento da população trans e LGB recém-conquistados vêm passando por questionamentos que poderão culminar em retrocessos capazes de, futuramente, modificar as conquistas já legitimadas. Nesse sentido, podemos citar a exclusão/retirada de alguns Planos de Educação estaduais e municipais, a menção, a discussão e o trabalho com questões cujo foco é a diversidade e a igualdade de gênero no âmbito escolar, contrariando flagrantemente as Diretrizes Nacionais da Educação (CARVALHO, 2015). Acredita-se que a ausência dessas discussões dentro do universo escolar vulnerabiliza as pessoas trans em relação às opressões/violências vividas dentro e fora da escola.

Outras questões pautadas neste contexto atual se referem à tentativa das casas legislativas em confrontar a implantação da Resolução 12/2015 da Secretaria de Direitos Humanos da Presidência, que legaliza, nas escolas, a adoção do nome social, a utilização de banheiros adequados, e a utilização de roupas e acessórios adequados à expressão de gênero escolhidas por transexuais e travestis.

\section{Participantes da pesquisa}

Apresentamos, a seguir, o/as participante $/ \mathrm{s}^{6}$ da pesquisa por meio de uma breve exposição de suas histórias contribuindo, assim, para uma melhor compreensão de suas narrativas:

Baby. Mulher transexual, 24 anos, nascida em São Paulo. Viveu quase toda sua infância e adolescência em uma capital nordestina e reside na sua cidade de origem. Negra, de classe baixa, atualmente é vendedora em loja de cosméticos. Cursa o segundo semestre de Gestão em Turismo numa instituição Federal em São Paulo. Declara que sempre teve uma relação tranqüila com os pais. Tem uma irmã com quem divide um apartamento. Seu processo de transição aconteceu no período escolar, entre os 17 e 18 anos, mas com 14 anos Baby já havia conversado com pais, alegando que gostaria de realizar a cirurgia de transgenitalização. Só mais tarde, porém, começou a terapia hormonal. Trabalhou em vários lugares antes de acessar a Universidade, geralmente em subempregos, alegando que a ausência de aceitação de sua transexualidade gera todos os tipos de precarização e exploração. Com seus documentos já retificados, afirma que conseguiu se estabelecer em um trabalho melhor remunerado e ter aceita em sua singularidade. Participou de um cursinho popular para pessoas trans e prestou o ENEM, conseguindo acessar uma vaga na universidade.

Bethânia. Mulher transexual, 29 anos, nasceu em uma cidade de grande porte do interior do Rio de Janeiro, mas viveu quase toda sua infância e adolescência em cidade litorânea do mesmo Estado, atualmente residindo na capital. Mestiça, de classe baixa, trabalha como profissional do sexo. Cursa o segundo semestre de Artes Cênicas em uma universidade confessional no Rio de Janeiro. Declara ter passado por várias brigas entre os familiares, relacionadas sempre a questões religiosas: seu pai era o pastor da maior Igreja Evangélica de sua cidade, o que foi um grande empecilho para efetivação de uma relação familiar menos conflitante. Tem também dois irmãos do sexo masculino, mais velhos. Seu processo de transição aconteceu no período escolar, aos 18 anos, mais especificamente no período de férias finais o que, segundo ela, causou menos desconforto, pois iniciou o próximo ano letivo como Bethânia. Trabalhou em várias funções e locais antes de acessar a Universidade, como garçonete, balconista, chapeira de lanchonete, atendente de loja, mas sempre sem registro, 
sofrendo todos os tipos de precarização e exploração causados por sua transexualidade. Trabalhou em alguns períodos com prostituição de rua, atividade que exerce exclusivamente há algum tempo, nas ruas da Lapa, Rio de Janeiro. Em 2015, conheceu um professor do cursinho preparatório "Prepara Nem", que lhe convenceu a voltar aos estudos e, hoje, está no segundo semestre de artes cênicas em uma universidade confessional no Rio de Janeiro.

Cássia. Mulher transexual, preferiu não revelar a idade, aparentando ter por volta de 35 anos. Nascida em São Paulo, capital, mas atualmente reside no Rio de Janeiro há dez anos com sua mãe e duas amigas. Branca, de classe baixa, está desempregada e realiza programas sexuais eventualmente. Cursa o segundo semestre de Jornalismo em uma universidade privada. A mãe era dona-de-casa e o pai, policial militar aposentado. Viveu entre a casa e as ruas de São Paulo entre 5 e 12 anos, período em que se envolveu o meio LGBT, principalmente com travestis profissionais do sexo. Acabou, depois de um tempo, coabitando com as mesmas. Seu processo de transição aconteceu tardiamente, há 15 anos atrás e, segundo ela, não foi com a idade que gostaria, mas sua justificativa era o medo de sofrer mais agressões, pois no período escolar, por ser mais "feminina", passou por várias situações que lhe causaram certo pânico de se assumir enquanto transexual. Refere ter tido muitas dificuldades para ter acesso à universidade, causadas por preconceito e pela situação econômica desfavorecida, o que a obrigou, desde cedo, a trabalhar como profissional do sexo.

Cazuza. Homem transexual, 26 anos, nasceu em Recife, onde habita até hoje. Branco, de classe baixa e bolsista, cursa o segundo semestre de Química em uma universidade pública na mesma cidade. Sua família é constituída por 4 pessoas: pai, mãe e mais um irmão. Declara que passou por várias brigas com os familiares, porque eram muito violentos, agressivos e hostis. Todas as brigas foram relacionadas com o seu processo de transição, sendo expulso de casa quatro vezes. Com 20 anos assumiu sua transexualidade e saiu definitivamente da casa de seus familiares. Seu processo de transição aconteceu depois do período escolar, entre 18 e 19 anos e alega que sua inserção nos movimentos sociais contribuiu para sua aceitação e, principalmente, para busca de inclusão social. Refere que, por conta da militância e ativismo, desde que passou pelo processo de transição, nunca conseguiu exercer um emprego formal. Mesmo já inserido no contexto universitário, ainda se sente vulnerável, tanto pela questão de sua transexualidade, quanto por questões financeiras. Afirma que a assistência estudantil recebida é muita baixa e o auxílio alimentação não dá conta de suprir suas necessidades existenciais, o que obriga, às vezes, em pensar maneiras de burlar a ausência financeira e buscar outras fontes de renda, incluindo o mercado sexual.

Elza. Mulher transexual, 41 anos, continua vivendo na cidade de seu nascimento, Sorocaba-SP. Negra, de classe baixa, desempregada, cursa o segundo semestre de pedagogia em uma universidade pública. Sua família é constituída por 6 pessoas: pai, mãe e duas imãs e um irmão caçula. Declara que passou por várias brigas entre os familiares, geradas principalmente pela ausência de diálogo sobre questões voltadas à sexualidade. Seu processo de transição inicial aconteceu no período escolar, com 15 anos mais ou menos, mas relata que sempre sentiu essa vontade de ser feminina. Aos 17 anos, com a separação dos pais, percebeu a necessidade de ajudar em casa e trabalhou durante 17 anos em hospitais públicos como ajudante de enfermagem, profissão já exercida pela mãe. Refere que exonerou de um cargo efetivo por cansaço, mas alega que também ocorreram casos de transfobia no ambiente de trabalho, justificando o abandono de um emprego em que supostamente tinha certa estabilidade. Após várias idas e vindas, em tentativas de realizar um curso superior, hoje está fazendo o segundo semestre do curso escolhido.

Gal. Mulher Transexual, 22 anos, nascida e criada em uma favela carioca. Branca, de classe baixa, trabalha como estagiária em um órgão público voltado para a população LGBT. Cursa o segundo semestre de Serviço Social em uma universidade confessional no Rio de Janeiro. Filha de uma família cristã evangélica constituída por 5 pessoas (pai, mãe e dois irmãos), atualmente mora só com a mãe e irmãos. Declara que passou por várias situações de violência física em casa por querer usar roupas femininas e cabelos compridos e por sua sexualidade afrontar preceitos de origem religiosa. Refere que desde muito pequena teve muitos problemas por ser muito feminina. Sua transição foi bem cedo, comenta que sempre buscou e quis ser mulher. Durante o período escolar Gal passou por diferentes situações, que incluem desde agressões físicas a verbais, gerando desconfortos e, consequentemente, sentimentos de não pertencimento àquela realidade onde quase ninguém a compreendia.

Nara. Mulher transexual, 31 anos, nasceu no interior do Estado de São Paulo, mas hoje em dia reside na capital com sua companheira. Branca, classe média, bolsista e escritora, atualmente está no último ano de doutorado em uma universidade pública no interior do mesmo Estado. Sua família de origem é constituída por 5 pessoas (pai, mãe e uma irmã e um irmão mais novo que ela). Declara que houve rejeição inicial por familiares principalmente no inicio do processo de transição, mas alega que de certa maneira foi tranqüila, nada comparando com outras/os transexuais que sofrem todo tipo de exclusão. Seu processo de transição aconteceu mais tardiamente. Declara que ao entrar em contato maior com militantes trans no contexto 
universitário, foi ficando mais confiante e aceitando sua singularidade. Por ter crescido numa família de classe média e ter tido acesso a bons colégios, descreve que sempre teve boas notas, o que facilitou seu acesso rápido à universidade. Ao terminar o curso de letras já ingressou no mestrado e, em seguida, no doutorado. Declara que não precisou trabalhar para se manter durante sua vida universitária. $\mathrm{O}$ apoio familiar financeiro para os estudos tornou-se um facilitador para que ela obtivesse boa qualidade de ensino, inserção e possibilidade de crescimento no contexto acadêmico, diferentemente de outras/os pessoas trans que também fazem parte deste artigo que, sem algum tipo de política de auxílio, não teriam condições para a manutenção de seus estudos.

\section{Da escola regular ao sonho da universidade}

A infância e o período escolar, para a maioria das travestis e transexuais, são os períodos em que muitos dos conflitos e transformações relacionados à sua expressão de gênero tornam-se mais evidentes. Segundo Louro (1997), no ambiente escolar constroem-se, em vários momentos, situações que legitimam separações entre gêneros, estimulando a competição e, posteriormente, a perpetuação de preconceitos generificados. Ao realizar uma separação entre meninos e meninas, em atividades escolares, em grupos de estudo ou em propostas de competições, provoca-se, por exemplo, brincadeiras que podem ridicularizar ambos. Por outro lado, também podem ser construídas na escola várias situações que representariam um "cruzamento de fronteiras", ou seja, circunstâncias em que as fronteiras ou as demarcações entre os

gêneros são atravessadas. "É provável que para algumas crianças - aquelas que desejam participar de uma atividade controlada pelo outro gênero - as situações que enfatizam fronteiras e limites sejam vividas com muita dificuldade". (LOURO, 1997, p. 79).

Essas fronteiras generificadas na escola, em vários casos, relacionam-se a situações de violência e constrangimento. Antes mesmo do processo de transição de seus corpos, o preconceito por serem mais "femininas" é frequentemente descrito nas falas das participantes dessa pesquisa:

Cássia: A primeira vez que eu fiz o ensino médio, o $2^{\circ}$ ano, e eu não tinha transicionado ainda, ia como
"menino gay", mas tinha toda uma questão de perseguição mesmo porque eu era muito feminina, eu usava
cabelo chanel, baby look, calça justinha, mesmo para gay eu ainda tinha um estereotipo que era muito além
do que "poderia socialmente" ser aceito, porque não era isso esperado de um rapaz. Então eu sofria muita
perseguição mesmo, de correram atrás, de bater, me trancar no banheiro, de ás vezes me forçar a fazer sexo
senão eu iria apanhar e ir falando para todo mundo, iria falar que eu dei em cima, essas coisas todas que
acabavam impossibilitando eu de ir...

A abjeção ${ }^{7}$ das pessoas que, muitas vezes, fogem à norma de gênero, como é o caso das/os transexuais e travestis, corresponde a um dos pilares para a manutenção da cisheteronormatividade ${ }^{8}$. A escola acaba sendo uma das instituições centrais para o desenvolvimento deste projeto. Em suas narrativas, as pessoas trans referem que não há aceitação de suas expressões de gênero, tampouco respeito às suas singularidades.

Embora a escola tenha cumprido o papel principal de reprodutora e mantenedora de uma visão cisheteronormativa e binária das relações sociais, ela também continua sendo um espaço importante para se construir e fortalecer, ou desconstruir, debates e questões que contribuem para desmistificar e transformar a vida das pessoas, como os processos históricos e sociais de marginalização, invisibilidade, violência e discriminação da população LGBT, em geral (GARCIA, 2009). 
Em pesquisa sobre as várias formas de violência sofridas por travestis e transexuais no contexto brasileiro, TONELI et al., (2015) constatam que as políticas que mencionam o uso do nome social ainda são muito recentes e não são plenamente absorvidas no cotidiano escolar. Observam também que essas conquistas estão ameaçadas, pois, no último Plano Nacional de Educação (PNE), as menções pela promoção das igualdades racial, regional, de orientação sexual e de gênero foram retiradas do texto apresentando-se, desta maneira, um retrocesso em relação às políticas de inserção e ampliação de direitos à população LGBT em geral.

A retirada do termo gênero dos Planos de Educação, nos níveis federal, estadual e municipal tem
sido recorrente em 2015, a partir dos grupos de parlamentares associados a fundamentalismos
religiosos que se utilizam de conhecidos argumentos de base essencialista biológica: o homem é
homem e mulher é mulher, conforme assignado pelo seu sexo biológico. (TONELI et al., 2015, p.
94).

A maioria das interlocutoras terminou o Ensino Médio em um tempo acima do padrão relativo à sua faixa etária, o que foi atribuído por elas à vivência de um estilo de vida incompatível com a rotina escolar, como a associada à prostituição. Para TONELI et al. (2015), quando a escola falha no acolhimento e no oferecimento de condições para a permanência às pessoas trans - por meio do uso do nome social; acesso ao banheiro adequado à sua expressão de gênero; e o combate da violência cotidiana por outros alunos, docentes e funcionários do espaço escolar, dentre outras ações - "[...] ratifica-se a prostituição como saída para a sobrevivência, uma vez que restam poucas chances de qualificação para o trabalho e outras formas de sustento". (TONELI et al., 2015, p. 94).

Além de terem sua cidadania sistematicamente interditada, as travestis e transexuais normalmente deparam com problemas de desigualdade de classe, uma vez que uma grande parte vem de famílias da base da pirâmide social. Pelo preconceito e exclusão sofridos, ficam sem possibilidades de ascensão social permanecendo, assim, sem acesso à educação formal e universitária, exploradas pela necessidade de se prostituir, ou em subempregos e, consequentemente, empobrecidas.

Se a permanência (e, supostamente, o sentimento de pertencimento) ao ambiente escolar é, para a maioria das travestis ou transexuais, algo sujeito a muitos conflitos, a evasão contribui ainda mais para a dificuldade de inserção no mercado "formal" de trabalho. Isso se intersecciona com a discriminação e violência sofridas em outros espaços, como pode ser observado nos dados da pesquisa Política, Direitos, Violência e Homossexualidade, realizada durante a 10ª Parada do Orgulho GLBT em São Paulo de 2006:

Confirmando dados de pesquisas anteriores, as pessoas trans são as mais vitimizadas em todas as categorias, com índices muito maiores que os relacionados a homossexuais e bissexuais. Os relatos de violência sexual são os mais discrepantes entre trans e outras categorias: nesse caso, o percentual de trans que relatam ter sofrido violência sexual (30\%) é 5 vezes maior do que o dos homens homossexuais (6\%), o maior entre as outras categorias. (FACCHINI et al., 2007, p. 66).

Os contratempos nos ensinos fundamental e médio, sem dúvida, impactam na decisão de muitas pessoas trans em não prosseguir nos estudos, dúvida que apareceu em algumas narrativas, como nesta, de Gal: 
Gal: Eu acho que tem todo um processo até você chegar à faculdade, até uma pessoa trans chegar à faculdade ela já passou por diversas etapas dentro da educação que tirou totalmente a vontade delas de querer continuar estudando, e ate mesmo impediu ela chegar a uma faculdade por ela não conseguiu concluir o ensino anterior. (...) Tem diversas coisas para pensar, uma pessoa trans que conclui o ensino médio ela começa a pensar na faculdade, porque antes disso, a gente tem sonho de querer aprender alguma coisa, a gente tem vontade, mas a gente sabe os problemas que podem acontecer por a gente estar dentro desse ambiente.

São frequentes nos discursos de pessoas trans os sonhos de acesso, aceitação e permanência dentro de uma universidade, que correspondem ao reconhecimento do direito de serem consideradas/os iguais e buscarem o respeito enquanto futuras/os profissionais. IRIGARAY (2010), ao pesquisar travestis e transexuais que conseguem uma inserção no mercado formal de trabalho, afirma que, para que haja manutenção de seus empregos, geralmente, as empresas exigem que suas/seus empregadas/os necessariamente separem suas características trans e interesses pessoais dos profissionais, reprimindo sua dimensão individual ao "bem comum” organizacional da empresa que as/os contrata.

Esta visão é limitada, uma vez que se pode identificar a presença de racionalidades concorrentes na organização, e que, portanto, os indivíduos não apresentam qualquer tipo de clivagem entre quem são, como homens e mulheres, dos papéis e exigências de suas profissões. No caso das travestis, sua identificação com o que foi construído como socialmente feminino tende a ser rejeitada fora das indústrias da moda, entretenimento e artes, nas quais, pelo contrário, chega a ser valorizada. Estes foram os casos dos maquiadores, cabeleireiros e costureiros entrevistados. (IRIGARAY, 2010, p. 10-11).

A obrigatoriedade e a legalização do uso do nome social em diversos contextos tornaram-se elementos contribuintes para a visibilidade, ampliação e, principalmente, ao acesso dessa população a diversas instituições. O possível ingresso nas instituições ensino superior, com a utilização do nome social no exame do ENEM, caminha neste mesmo sentido. CARRARA e CARVALHO (2013) consideram que a noção de travestis e transexuais como população alvo de políticas públicas, mesmo implementadas por meio de ONGs, em algum nível, já indica sua consideração enquanto cidadãos/ãs.

Além do projeto Transcidadania, realizado pela prefeitura de São Paulo desde 2015 descrito anteriormente, existem ao menos sete cursinhos preparatórios, com pequeno ou nenhum apoio por parte do poder público, organizados por ONGs voltadas à escolarização nos vários níveis desta mesma população. São eles: o Educa Trans, que oferece curso de alfabetização no município de São Paulo; o Coletivo Transformação (São Paulo); o Trans Enem (Belo Horizonte e Porto Alegre); o Transviando o Enem (Salvador); e o Prepara Trans Goiás (Goiânia) - todos oferecendo cursinhos preparatórios específicos para travestis e transexuais para a realização do ENEM; o Prepara, Nem! (Rio de Janeiro) que, além do cursinho preparatório, ainda acolhe na sua casa sede, travestis e transexuais que se encontram em situação de rua ou que não possuem condições para pagar um aluguel. (BOECKEL, 2016).

Gal, Cássia e Bethânia foram alunas no Prepara, Nem!:

Bethânia: (...) antes de eu viajar para casa dos meus pais, eu conheci o professor de Sociologia, do Prepara Nem, e ele me apresentou o cursinho, conversou, me explicou, tal e tudo mais. Isso na rua, na Lapa, passou, eu já conhecia algumas das meninas que estudavam lá, eu tinha uma vaga ideia do que era, e viajei com isso na cabeça, e quando voltei, eu já voltei com essa ideia: "Eu vou entrar pra esse cursinho e vou entrar pra uma faculdade". (...) E fiz menos de um mês de Prepara Nem, e vim fazer o vestibular, dia 10 de outubro, com a cara e a coragem. 
Para Bethânia e Baby, além de ajudar com os estudos, o contato com outras/os transexuais e travestis contribuiu para a desconstrução de seus preconceitos.

Bethânia: Foi muito boa essa experiência, eu me afastei um pouco do Prepara Nem por umas questões de opiniões diferentes, mas sou muito grata pelo que eles fizeram por mim. Muito mesmo, tem pessoas ali que mudaram a minha vida completamente, não só a minha vida acadêmica, como a minha vida em si, porque até eu conhecer o grupo eu tinha também muitos preconceitos que eu fui desconstruindo ao longo da minha jornada junto com aquele grupo todo, foi muito bom pra mim, foi muito válido em tudo participar daquele projeto.

Baby: E comecei as aulas com eles, e como o cursinho era um projeto piloto, era só uma vez por semana, não tinha muito conteúdo, assim, mas a questão de empoderamento das pessoas trans que são maravilhosas, me deu mais força para conseguir.

\section{A entrada da Universidade}

É importante considerar que as questões relacionadas à "democratização" da educação superior em anos recentes entraram fortemente na agenda das políticas públicas. É possível supor que uma parcela da população trans tenha sido favorecida pelas políticas de ampliação ao acesso universitário para a população de baixa renda, criadas pelo Governo Federal a partir de 2007. O Programa de Apoio aos Planos de Reestruturação e Expansão das Universidades Federais (Reuni), o Programa Universidade Para Todos (Prouni), e a adoção do Sistema de Seleção Unificada (Sisu), incluindo, nesse último, as políticas de acesso por meio de cotas sociais e étnico-raciais, foram medidas governamentais que geraram maior acesso de estudantes de origem popular à universidade pública.

A crescente demanda por educação superior tem resultado num grande incremento de matrículas e, obviamente, de tipos diversificados de instituições. De um lado, esse fenômeno da expansão dos sistemas superiores, especialmente no que se refere ao acolhimento de importantes segmentos da população tradicionalmente excluída, corresponde a um legítimo projeto que busca diminuir, ainda que de forma muito restrita, as desigualdades sociais. Com isso ganham os indivíduos incluídos, que se beneficiam da educação para seu crescimento pessoal e uma inserção mais favorável no mundo do trabalho; e ganha à sociedade, que passa a incorporar mais gente com maior capacidade de participar construtivamente nas esferas públicas da vida social e política e nos âmbitos profissionais e econômicos da produção e do consumo. (DIAS SOBRINHO, 2013, p. 116).

A inclusão, nas universidades, de segmentos anteriormente delas excluídos, pela via das políticas de democratização para o Ensino Superior, e a presença crescente dos cursinhos preparatórios para pessoas trans foram identificados como facilitadores do acesso à universidade pelas pessoas aqui pesquisadas.

Para DIAS SOBRINHO (2010), as políticas de democratização do ensino não devem apenas criar condições em que todos e todas possam estudar, mas principalmente deve assegurar a igualdade de oportunidades, inclusive do ponto de vista qualitativo. No caso das/o transexuais pesquisadas/o, as dificuldades vão desde pagar a matrícula da universidade, moradia, alimentação, ou seja, de assistência estudantil em geral, à relação de docentes e funcionárias/os que não são formadas/os adequadamente para isso. Observamos que é insuficiente o acesso sem que se assegure a permanência, pois se trata de pessoas que, geralmente, carregam profundamente as marcas da abjeção intrínsecas em seus corpos e em suas histórias, como pode ser descrito na fala de Gal, sobre o medo de estar no meio universitário: 
Gal: Como eu disse para você, o ambiente escolar não era algo agradável pra mim, então a universidade também é um ambiente escolar, então vir para cá pode remeter esses tempos de estudos, que geralmente é ruim e no meu caso foi bem ruim pra mim. Os transtornos que a gente pode passar aqui dentro como não ser respeitada, nesses ambientes formais a gente sempre vai ter problema, porque vão fazer a gente passar por alguma vexatória, em algum momento vão me chamar no masculino, em algum momento, vão me chamar pelo nome de registro. (...) Então eu acabo evitando um pouco esses espaços em que eu vou ter problemas assim, fora por ter essa evasão de pessoas trans no ambiente no fundamental ainda, também conta para que o acesso a faculdade ser mais difícil para as pessoas trans. As pessoas trans não estão nem concluindo o ensino fundamental, a gente não está falando nem de pessoas trans dentro do ensino médio, a gente quer falar de pessoas trans dentro da faculdade. É bem complicado!

É importante ressaltar que, em relação às questões de acesso e permanência no ambiente universitário, são diversas as adversidades descritas por cada uma/um das/do interlocutor/as, o que requer uma descrição mais detalhada.

Elza, atualmente estudante de Pedagogia em uma universidade federal, já realizou o curso técnico em enfermagem, iniciou a graduação em enfermagem, uma graduação em pedagogia particular, e não concluiu por questões financeiras e ausência de financiamento universitário:

Elza: Fiz dois anos lá de Enfermagem, estava tudo ok. Só que nessa época eu comecei a tomar muito
hormônio, e foi nessa época aí, que logo em seguida eu casei (...) Bom, enfim, e aí eu lembro que eu me
desestimulei, pela questão financeira, que na época eu lembro que eu perdi uma bolsa lá, que para mim ia
significar muita coisa, porque o curso era muito caro, FIES não se conseguia, era muito dificil conseguir o
FIES. (...) Era um curso que custeava, na época, 700 e lá vai cacetada por mês, com desconto ainda. E fora
o custo, né, de vida universitária, que era livros, então isso foi me desestimulando, eu acabei desistindo do
curso por causa disso. As pessoas 'não, continue porque você vai até o fim, a gente assina a lista, os
professores dão um jeito, depois você renegocia a dívida (...). Justo nessa época da bolsa, que eu perdi a
bolsa e eu também não estava conseguindo o FIES, inventaram de colocar essa maldita dessa catraca.
Encheram de catraca. Como é que a gente vai fazer para entrar?

Com essa desistência, Elza resolve continuar no próximo semestre, só que mudando para o curso de pedagogia em EAD, na mesma universidade. Desiste novamente e, no outro ano, realiza o ENEM e consegue ter acesso ao curso de pedagogia presencial em uma universidade federal. Os motivos de sua última desistência não ficam claros em sua narrativa. Quando questionada sobre outras dificuldades pelas quais passou ou passa, principalmente por estar estudando e ser uma mulher trans dentro de uma universidade, e se deve haver investimentos públicos específicos para esse grupo, Elza é categórica:

Elza: Ser Negra, a negritude, a transexualidade, a pobreza, porque se você já nasce negra transexual em uma família pobre, a coisa já muda de figura. Tudo isso conspira para que a sociedade automaticamente já coloque você à margem da margem, entendeu? Não vai dar, não vai dar emprego. Não vai dar. Você veja bem, tem 20 vagas ali, tem uma vaga, vamos pôr assim, aparece uma moça branca e não trans, ah, não vão dar para a transexual negra.

Elza coloca em pauta uma questão relevante que vem sendo discutida e questionada dentro do transfeminismo ou feminismo transgênero, acerca da discriminação interseccional. JESUS (2015) identifica a fundamentação do transfeminismo no processo de consciência política e de resistência das pessoas trans, que se baseia teoricamente no feminismo negro, particularmente no que diz respeito aos conceitos de “(...) interseccionalidade de opressões, de não-hierarquia de opressões, de denúncia de vinculação de gênero a modelos supraracistas de quem seja, homens ou mulheres”. (JESUS, 2015, p. 20). 
Baby, estudante de Turismo em uma Universidade Federal, trabalhou e continua trabalhando para se manter. Conseguiu ter acesso à universidade pelo ENEM, principalmente por ter sido bem colocada na redação:

Pesquisador: O que te motivou a fazer esse curso?

Baby: Foi o SISU. A questão dos pontos (risos). Os pontos que eu consegui no ENEM, porque eu fui muito mal eu não me preparei o suficiente para fazer a prova bem. Eu detesto meritocracia no sistema de ensino, acho uma bosta. A questão da forma que é cobrado para que você consiga entrar, eu acho muito mecanizado. É muito complicado para um ser humano conseguir fazer, conseguir entrar, ingressar em um curso que a pessoa realmente goste. Mas como o tema da redação do ENEM foi "A persistência da violência contra a mulher no Brasil", e eu já tinha muito contato com o feminismo, transativismo, então eu soube o que falar. Eu falei sobre transexualidade no meu texto, falei sobre políticas públicas que são ineficazes, sobre cultura do estupro, sobre sentenças judiciais que são tendenciosas quando as mulheres são negras ou pobres ou transexuais e outros inúmeros fatores. Eu falei, consegui tirar 800 na redação e foi o que me deixou assim até bem colocada.

O medo do preconceito e os trabalhos precários que pessoas trans acabam sendo levadas a exercer dificultaram a decisão de Baby de voltar aos estudos.

Baby: Dificuldade de acesso, preconceito, mas eu sinto mais em questão, na questão do acesso ao mercado de trabalho, que é muito complicado, é muito fechado. Extremamente fechado. Eu trabalhei com telemarketing por oito meses, sai, recebi o seguro, fiz diversas entrevistas para outras empresas de telemarketing, com a minha diç̧ão simpática até, comparada como ótima comparada com de outros candidatos. Com a questão da documentação, quando eles tinham acesso, eu era barrada. Nunca passava. Em várias. Ai tive que descer mais ainda, trabalhei na bilheteria do [cinema x] quatro meses, e depois consegui esse emprego numa loja de cosméticos (...) Eu acredito assim, se a empresa não tem capacidade de entender o que acontece, de respeitar a situação das pessoas, ela não devia nem contratar. Eu penso assim, ou ter um mínimo de profissionalismo mesmo, porque é um pouco pesado. Mas eu fiquei muito tempo procurando sem conseguir, e quando eu consegui me estabilizar financeiramente, foi quando eu consegui pensar em voltar a estudar. Antes disso eu não teria como, porque eu não tinha como morar com os meus pais.

A discriminação no mercado de trabalho formal aparece de forma contundente na fala descrita.

Como apontado anteriormente, os trabalhos precários já fazem parte das existências de quase a totalidade das pessoas trans. RONDAS e MACHADO (2015), ao analisarem as condições sociais que envolvem a inserção profissional de travestis no mundo do trabalho, mostram que a maioria delas desempenha ocupações consideradas "femininas" pela sociedade.

Suas chances de conseguirem emprego junto a empresas que priorizam o contato com o público são menores, exceto no caso de empresas de telemarketing em que o contato não é visual. A história de vida das travestis é cheia de episódios de rejeição, o que gera obstáculos muitas vezes intransponíveis. Ainda é minoria entre as entrevistadas aquelas que, apesar dos obstáculos, procuram crescimento pessoal e profissional, conhecendo e exigindo seus direitos, e enfrentando as fortes reações da sociedade. (RONDAS e MACHADO, 2015, p.204).

Baby também alega que, mesmo sendo difícil e moroso todo processo de reconhecimento do nome social, sua utilização também foi um passo importante para se manter inserida no curso técnico e, depois, na universidade.

Baby: Eu acho que nome social é uma medida paliativa que é importante, no caso, na situação atual, que não existem leis de identidade de gênero, então o processo de retificação civil é muito complexo e você fica sempre à mercê do juiz, porque se você pegar um juiz ruim, você não vai conseguir. Se pegar um juiz bom, um juiz mais ou menos (...). Eu já usei, foi o que garantiu a minha permanência porque se eu não tivesse, eu não teria ficado, não teria terminado o técnico que eu fiz, mas não existe lei, inclusive para o nome social. Se você não tem, na ponta da língua, todas as leis que te garantem esse direito na questão, em âmbito 
público porque em âmbito privado ninguém te garante, você não consegue. Porque quando eu solicitei, eu tive que fazer, eu fui esperta de fazer uma carta de próprio punho, de levar as leis, decreto de lei, tudo que garantia esse direito para mim. A resolução, depois que foi emitida a resolução, em janeiro de 2015, para garantir que eles mantivessem o nome, e fica a critério do profissional que vai cadastrar, se vai fazer, se vai colocar um nome do lado do outro, se vai colocar dois nomes, se vai colocar um nome só, se vai permitir ou não. É tudo muito complicado. Como, geralmente, pessoas trans estão em situação de vulnerabilidade social, ninguém vai ter condições de entrar com uma ação, ou de ter respaldo jurídico, de saber o que vai ter que apresentar. É muito complexo. Eu acho que a lei de gênero facilitaria mesmo a questão, para facilitar a mudança logo, para as pessoas não terem que passar por isso ${ }^{9}$.

O amparo legal é extremamente importante para que as pessoas trans sejam minimamente respeitadas enquanto inseridas numa sociedade democrática de direito. ${ }^{10}$ Nota-se o quão é relevante o reconhecimento do nome social na concretização de suas existências. Mesmo já existindo um decreto que possibilita o uso do nome social no ENEM, Baby relata que esse isso é insuficiente, correspondendo a uma humilhação:

Baby: Ah não, o nome social no ENEM é outra ilusão, amigo. Eles colocam o seu nome social e o seu nome de registro em baixo, e você tem que assinar com o seu nome de registro, e na hora vai ser nome de registro. Não tem... não tem essa de nome social...

Pesquisador: Como?

Baby: A única coisa que muda é que você não vai ficar em uma sala com homens com o seu nome de registro, você vai ficar em uma sala com mulheres com o seu nome social, no caso.

Cazuza trabalhou e militou durante algum tempo e conseguiu ter acesso à licenciatura em Química em uma Universidade Federal por poder usar o seu nome social na prova do ENEM. Posteriormente, se manteve por conta de bolsas destinadas ao auxílio universitário e de trabalhos paralelos:

\begin{abstract}
Agora eu entrei na universidade porque, a gente conseguiu no ano passado aprovar uma resolução para garantir o uso nome social na universidade inteira da Universidade Federal, e ai foi possível, eu consegui fazer a prova do ENEM, usando o meu nome social, porque senão eu não teria feito, e consegui. Hoje em dia, eu não tenho nenhum constrangimento e não preciso explicar, porque dentro da burocracia, dos papeis de documentos dentro da universidade, todos tem o meu nome social. (...) a questão financeira também, eu fiz uma estratégia, eu estava trabalhando, de 44 horas semanais no Hospital das Clínicas, e ai pensei, vou colocar num curso a noite, que poderei fazer a transição melhor, do trabalho para o estudo. Eu saía do trabalho e ia para a aula, na aula eu consegui um estágio e obter uma bolsa, como eu tenho uma amizade, de construções políticas juntas com vários professores de lá, consegui a bolsa de estágio e poderei sair do trabalho e me dedicar só aos estudos, e é isso que estou fazendo hoje em dia. Tenho isenção no R.U. [restaurante universitário], só que isenção é da PROACE - Pró Reitoria de Assuntos Estudantis, alguns alunos em situação de vulnerabilidade financeira, ou que são do interior precisam. Eu fui, tentei e consegui, e a bolsa de estágio, foi dada pelos professores que são meus amigos e orientadores. A bolsa é no valor de $R \$ 380,00$.
\end{abstract}

Outra dificuldade localizada na vida de Cazuza está na ausência de acesso à "bolsa moradia": por ser nascido na Capital, esse tipo de auxílio só é ofertado para pessoas que migram do interior. Ressalta que, devido à baixa remuneração oferecida pela instituição, e não possuindo outro tipo de ajuda familiar, busca no mercado sexual uma alternativa financeira para se manter.

Cazuza: (...) estou querendo mudar para um kitnet, e é por isso que estou agora querendo desenvolver uma nova atividade funcional que é a prostituição, que eu vou poder ter mais grana para pagar meu aluguel inteiro e minhas contas, ter mais privacidade e poder fazer as coisas de uma forma legal, da maneira que gosto, de organização em casa. Também estou esperando o resultado do edital da bolsa de assistência estudantil, porque a bolsa que eu tenho é de estágio, além de não ter certeza que vou continuar com essa bolsa, pois pode dar uma "doida” na minha orientadora e ela me cortar, além de eu ter medo disso. (...) Se eu conseguir a bolsa da assistência estudantil, já vai dar para eu pagar com meu dinheiro, ai eu teria as duas bolsas de R\$380,00 cada uma, mas não tenho certeza ainda. É um dinheiro que consigo pagar meu aluguel e minhas contas sem precisar me prostituir (...) Fiz um programa no mês passado, fiz um anúncio 
num site da internet, apareceu três caras e acabei saindo com um, eu cobrando $R \$ 100$, 00, o cara tem que pagar também o motel e saí mais caro, por isso até se eu morar só, numa kitnet, é mais econômico e aparece mais clientes, é isso, estou nesse processo e espero que dê certo.

Bethânia, estudante de Artes Cênicas em uma universidade confessional, trabalha como profissional do sexo e tem o auxílio de uma bolsa integral oferecida pela reitoria da universidade:

Quando eu terminei o segundo grau, eu ganhei uma bolsa [em uma universidade privada] pra fazer educação fisica, só que eu iria pagar 200 reais e não sei quanto de mensalidade, e disso eu briguei com o meu pai, por causa disso, ele não tinha com me ajudar na época, tinha que fazer essa matricula, tinha que ser rápido senão eu iria perder, eu achei descaso da parte dele, então a gente brigou. (...). Quando saiu o resultado [da universidade que está cursando agora] eu quase perdi o dia da matrícula, porque não tinha como pagar dois mil e pouco para fazer a matricula e tive que conseguir chegar até a vice-reitor e ele me isentou da matricula. Depois foi um problema na minha cidade para eu pegar o meu certificado, porque não está pronto até hoje o meu certificado de conclusão do Ensino Médio. (...). Eu ganhei uma bolsa de 100\%, integral, filantrópica aqui da Universidade. (...). Eu ganhei bolsa mesmo porque eu não fiz nem o ENEM, eu só fiz o vestibular dessa universidade, nem outra faculdade, ou era essa ou não era nenhuma!

Cássia, estudante de Jornalismo em uma universidade privada, só conseguiu o certificado de conclusão do ensino médio após ser avaliada no ENEM. Permanece na universidade ajudada por bolsa de auxílio universitário (que a isenta de pagar mensalidade) e trabalhos paralelos que envolvem desde o mercado sexual até "bicos" como atriz.

Nós temos uma professora trans na universidade, que dá aula de direito, ela é advogada, inclusive foi ela que conseguiu as bolsas do Prepara Nem, foi onde eu acessei a universidade, através do Prepara Nem. O que ela me contou foi o seguinte, ela numa conversa comigo, sabendo a minha vontade muito grande de fazer faculdade de jornalismo, mas impossibilitada pelas questões financeiras e por falta do certificado (de conclusão do EM), foi na faculdade pedir um bolsa pra mim, aí conversando com a faculdade perguntaram que eu era e como que funcionava (no caso o cursinho), nisso o Prepara já estava funcionando como cursinho, então eles conseguiram 5 bolsas, uma dessas bolsas entrou eu, entrou [amiga], que também é do Prepara, que esta fazendo publicidade a noite.

Pesquisador: Você conseguiu o certificado junto com o ENEM?

Cássia: Sim, junto com o ENEM em 2015, quando eu me inscrevi no ENEM eu marquei a opção de valer como certificado do ensino médio.

Já Gal é estudante de Serviço Social em uma universidade confessional e faz estágio em um órgão governamental, estágio também obtido, conforme exposto anteriormente, por meio de políticas de inclusão para o segmento trans. Tem auxílio de uma bolsa integral oferecida pela reitoria da universidade e sobrevive por seus ganhos como estagiária.

Para ALMEIDA (2010), o simples acesso à universidade, sem qualquer política que vise à permanência, é insuficiente, pois:

Você consegue a bolsa, mas depois fica jogado - dificuldades de transporte, apostilas, xerox, livros, cursos, alimentação. Se você consegue uma bolsa integral, está implícito que é de renda baixa. A pessoa tem que trabalhar para se manter e não tem a vivência ampla da universidade, ter tempo para estudar, se ambientar no meio acadêmico. Trabalhando e estudando não atende a demanda de desenvolvimento do aluno e, no caso, ele só consegue um certificado de conclusão de curso. (ALMEIDA, 2010, p. 08).

São frequentemente narrados pelas/o participantes desta pesquisa o medo de que na universidade se reproduzam os mesmos preconceitos e exclusões que sentiram na escola e a necessidade de sobrevivência dentro de um universo que ainda não as/o compreende, além do sentimento de isolamento 
no contexto universitário frente à transexualidade. Quando indagadas se há outras pessoas trans no meio acadêmico, seja de alunas/os, funcionárias/os ou docentes, elas/ele dizem:

Gal: Somos minorias, somos 6 pessoas trans dentro de uma faculdade, olha quantas pessoas tem aqui. A gente é bem excluída ainda, por conta de tudo o que eu já falei sobre educação, mas eu acho que agora pelo menos a gente está chegando e prefiro ver com bons olhos, tentar ver com esperança que as pessoas trans agora estão entrando na faculdade, que é um passo adiante.

Elza: Na [universidade particular] eu não percebi. Talvez eu não tenha percebido, porque, talvez até existam lá, mas invisibilizadas pela heteropadronização você entendeu? Não sei se esse termo existe, no sentido de que é tão feminina que você não perceba que a trans esteja ali estudando, e também não queira falar sobre o assunto, e não queria militar em prol de nada. Eu sei que tem isso, viu. Ah, sim. Tinha a Malu. A Malu era uma transexual branca, de um bairro de classe, acho que média-baixa.

Após recordar dessa transexual que exercia certa passabilidade ${ }^{11}$, por ser muito feminina, Elza descreve uma situação de transfobia exercida por uma professora durante uma aula de anatomia na universidade, no curso de enfermagem:

(...) eu lembro que na aula essa professora tinha uma postura meio estranha, porque quando nós fomos na aula inicial de laboratório de Anatomia, eu lembro de que quando ela estava falando das peças anatomicas, surgiu uma pergunta lá 'como que eu posso doar meu corpo após morte para servir, para ir para a faculdade, para ser estudado?' 'Ai, você tem atender um série de critérios', eu falei 'nossa, não é assim'. Eu achava que qualquer pessoa que morresse, né, indigente ou que fizesse um documento em vida se disponibilizando pudesse. Ela falou "não, você não pode ter tatuagem, você não pode ter isso, não pode ter silicone, não pode ter... Porque nem para peça anatômica você servirá.'

Por outro lado, há problemas, como os relatados por Baby e Cazuza em relação à legalização de seus nomes, que envolvem processos burocráticos, morosos, gerando situações constrangedoras:

Baby: (...). Ai, quando saiu essa lista, o primeiro professor que puxou essa lista, homossexual, aqueles gays homofóbicos. Eu acho que a transfobia dentro do meio homossexual é muito grande. Demais, demais. Eu não entendo por que. Não consigo entender, mas é muito grande. Então, aí eu tive um ataque de raiva "Ai, fala seu nome. Seu nome não está na lista. Tem que ir na secretaria”. E eu fiquei muito nervosa, porque eu tinha acabado de entrar, tinha conhecido os meus amigos, não queria passar por isso. Porque eu já tinha retificado a documentação, foi um erro muito grande da secretaria. Até cogitei processar, mas a minha coordenadora do curso foi extremamente solícita. E ai eu fui, reclamei. Vazaram duas listas com o nome errado. E ai eu fui, eles retificaram, porque eu falei, conversei inclusive com o diretor, falei que eles não tinham justificativa porque eu já tinha apresentado documentação retificada no momento da matrícula, eles não tinham justificativa de ter puxado lista do SISU, nem de nada, porque se era um protocolo

Cazuza: A burocracia na universidade é muito complexa, é uma chatice, todas as universidades devem ser assim, e na U. Federal [...] não é diferente. Tem muitos lugares que a gente consegue usar, porque só depende do SIGA, que é o site/softwer que tem as informações dos estudantes, a gente acessa para saber a nota, os professores acessar para colocar a nota, etc. No SIGA a gente tem o nosso nome social lá dentro, quando os professores vão imprimir a ata de presença, o nome social está na lista também. Porém tem coisas que o nome social não está, tipo, no R.U. a gente tem três catracas que tem um sensor de biometria, e quando lê sua digital aprece seu nome no display, o meu ele está como Cazuza, porque, quando eu fiz o meu cadastro no R.U. eu já tinha direito ao nome social, mas tem outras pessoas trans que não atualizaram isso, que já estavam na universidade antes do nome social, e fizerem o cadastro com o nome civil, a pessoa está até hoje e tenta mudar e não consegue. Temos justamente que fazer que a diretoria tenha uma estrutura para fazer esse diálogo, tipo, vamos fazer uma reunião com a chefe do R.U. para poder atualizar, e em outros planos também, não sei como é na biblioteca, nunca fiz o cadastro lá.

As resoluções do nome social contribuem para a promoção do acesso e permanência de pessoas trans tanto na educação básica quanto na superior, ao garantir e respeitar sua expressão de gênero. Da mesma forma, é fundamental o acesso seguro aos banheiros correspondentes ao seu gênero pessoal, evitando situações vexatórias e diminuindo circunstâncias mais vulneráveis.

Gal: Até hoje eu não tive problema não, mas banheiro sempre é um problema pra gente (...) Então eu sempre imagino diversas coisas quando eu vou usar o banheiro e em algumas situações eu prefiro não usar 
o banheiro, mas aqui eu nunca tive problemas, eu sempre fico preparada. Eu só sinto segura no banheiro da minha casa, não é fácil, não me sinto segura (...). É bem complexo, eu entro, faço xixi, lavo minha mão e saio correndo, nem fico me ajeitando para não dizerem, "tem um cara aqui dentro e ele esta esperando pra ver algo..." Qualquer coisa que eu faça, vai dar motivos para eu passar por qualquer situação vexatória, então se não é em casa eu evito de usar o banheiro, mas se eu tiver que usar eu estou sempre preparada para usar o banheiro.

Mesmo sendo um homem trans e já ter transicionado há um tempo, Cazuza ainda tem insegurança ao usar qualquer banheiro:

Cazuza: Como eu sou homem trans, eu tenho muita passabilidade, ninguém percebe, sabe de nada, o problema que tem muitos banheiros que são acabados, destruídos, quebra fechadura, o meu constrangimento é ter que usar um banheiro masculino e ele não ter fechadura, aí é complicado. Na biblioteca central por ex. eu não pego livro, mas eu vivo lá, o banheiro do térreo não tem fechadura e eu tenho que usar o feminino o tempo todo. Da para usar quando é individual, quando é um banheiro coletivo, eu não posso fazer isso, eu não conseguiria entrar num banheiro feminino, mas quando é uma cabine só, ai eu consigo, isso é meu único constrangimento.

Pesquisador: E em banheiros públicos?

Cazuza: Quando não tem fechadura é dificil e quando só tem mictório, impossível.

Bethânia, por cursar Artes Cênicas, tem esse aspecto facilitado na universidade, pois:

O banheiro nosso é unissex, no caso do laboratório de Artes Cênicas, que é um pequeno teatro, com um banheiro grande e fechado, só os alunoxs do curso que o utilizam (...). Mas quando eu uso o banheiro do prédio, um banheiro comum, que tenho uma aula que lá, quando eu entro no banheiro feminino do corredor, eu nunca, nunca vi uma menina falar nada, se sentir desconfortável com a minha presença, entro e saio normal. Como em qualquer ambiente aqui...

Nota-se como a utilização do banheiro para pessoas trans envolve não só a questão legal, mas também uma mudança de costumes, ou seja, de aceitação por parte do restante da sociedade.

Nara: (...) Eu quero que as pessoas se acostumem com mulheres trans no banheiro feminino, eu quero que elas sintam a segurança que estão com uma mulher trans ou travesti no banheiro, não com um homem se aproveitando daquele espaço, entende, então é sempre difícil até hoje, por ex. vou no shopping, teve um dia, eu estava com a minha namorada e ela falou vamos no banheiro e eu não consegui, eu não estava sentindo confiante de que era tranqüilo para mim em entrar no banheiro, e ela fala, não, nada a ver, coisa da sua cabeça. Mas tem dias que eu não sinto no direito de expor para as pessoas passar por esse desgaste, porque é um desgaste. As pessoas trans estão começando agora, a se fazer notar, a se impor, a conseguir ocupar espaços na sociedade e ai a sociedade esta sendo obrigada a repensar os seus espaços, suas lógicas e seu funcionamento.

Outro aspecto que se relaciona à falta de acolhimento da população trans nas universidades é o que se refere à ausência de discussões de gênero e sexualidade em seus cursos:

Gal: Mais questão de expor o nome civil, me chamar pelo nome masculino, ou até mesmo quando algum puxa assunto que inclui gênero ou algo assim dentro da sala, acabam falando alguma besteira dentro do senso comum e acaba me atingindo, mas eu vejo que é mais por eles não terem se ligado que tem uma pessoa trans aqui dentro. Eles precisam saber como lidar com uma pessoa trans e o que vai atingi-la. Eu ainda estou no $1^{\circ}$ período, espero que no $3^{\circ}$ não ver mais isso. (...) Já surgiu assim [durante as aulas regulares], mas nenhuma aula que falasse sobre isso, nem acho que vá ter, acho que as pessoas trans dentro da faculdade se posicionar para que as pessoas dentro da faculdade saibam que são pessoas trans, porque se não for da gente ouvindo elas não vão saber o que é...

A convivência entre corpo docente é descrita como aparentemente pacífica, ressaltando-se a observação anterior, de que esses relatos se referem à comparação com outros espaços muito mais excludentes, mas as ausências de debates ainda podem gerar situações vexatórias.

Nara refere que sofreu retaliações por conta da militância feminista, mas, embora tenha sido acolhida enquanto trans, questiona o quanto a universidade é um lugar "fora da realidade": 
Nara: O que me trouxe inconvenientes foi a questão da militância, eu costumo dizer que meu ex. orientador né, tive que trocar de orientador durante o doutorado, o que aconteceu que o meu ex. orientador me aceitou trans, não me aceitou feminista, o ambiente universitário muito machista, não esta disposto a aturar uma figura que estivesse ali botando o dedo na ferida, falado que isso aqui é machista, que tal comportamento é inadmissivel dentro do espaço universitário, dentro de um espaço de segregação de mulheres, tipo de valorização do homem que denota virilidade, coragem, audácia, essas coisas babacas e suicidas, então, não! A militância passa a ser uma questão muito importante na minha vida, o doutorado que antes da transição eu depositava todas as minhas expectativas de realização pessoal, vai para segundo plano total, faz dois anos que eu não sou muito produtiva no doutorado. Eu passei por coisas desse tipo na universidade, mas nunca deixei que isso me oprimisse. (...) Eu sinto a necessidade de ter um dialogo com tudo isso que está acontecendo ao meu redor, pois quando eu sair da bolha, da universidade, vou precisar de um mundo que saiba me acolher. Começo a ter que usar dessa blindagem que a universidade me oferece para abrir brechas no mundo.

Sobre o relacionamento com colegas e a realização de atividades conjuntas, os relatos são também de relativa aceitação:

Cássia: Olha eu fui para lá preparada para uma guerra, fui gratamente surpreendida, os colegas todos me acolheram, não tenho problema nenhum com ninguém, se alguém tiver problema comigo fica bem velado, não chegou em mim nada, pelo contrario, me convidam pra grupo de trabalho, tenho toda convivência tranqüila e normal dentro da sala de aula. Eu quero deixar claro que a minha experiência não é regra é uma exceção por incrível que pareça é porque você tem noticias todos os dias de meninas que tem dificuldades na faculdade

Gal: Tudo tranqüilo, pelo menos não tive ate hoje ninguém que questionasse minha identidade e vejo que eles lidam com a minha identidade de uma maneira bem natural, aliás, se não fosse eu a puxar o assunto sobre transexualidade lá, iriam tratar de uma maneira natural eu ser uma mulher como qualquer outra, não iriam questionar isso, nem causar nenhum problema com isso, só depois que eu fui fazer uma piada por eu ser trans e ai eu abri uma porta para as pessoas começarem algumas perguntas...

Esses depoimentos mostram o desenvolvimento de estratégias diversas para resistir frente à transfobia existente em muitos espaços. Percebe-se como é importante e necessário debater e discutir questões relacionadas à diversidade de gênero e sexualidade em todos os âmbitos educacionais, que vão desde o ensino fundamental, passando pelo médio e continuando no universitário, pois é notório que o preconceito e a discriminação são gerados pela ausência de compreensão da diversidade de corpos e expressões de gênero, principalmente nestes ambientes e, de maneira menos "visível", nas universidades. É necessário tornar esse debate amplo e criar meios de desenvolver ações que possam concretamente transformar a realidade e tornar a aceitação e respeito para com as pessoas travestis e transexuais reais.

\section{Cenários possíveis}

Para além das conquistas sociais obtidas em uma esfera macro, sem dúvida alguma a militância trans nos espaços universitários coloca-se como uma necessidade premente para sua transformação em ambientes mais inclusivos para os segmentos trans. Nos diálogos das participantes dessa pesquisa, para além das ações governamentais, a militância e a participação em movimentos sociais tornaram-se essenciais na busca de suas conquistas:

Cássia - Exerço, sou militante efetivamente e com consciência desde 2010, porque eu acho que ser travesti ou transexual você já militante ao acordar e ir para a padaria, já uma militância mesmo sem você querer, fiz parte de ONG, hoje não, faço parte do movimento do coletivo que é o Prepara Nem que é um movimento político, além de tudo, pra além dos muros da escola, não visa só cursinho e Enem. E sou a pessoa Cássia que as pessoas acabaram conhecendo, ontem mesmo eu estava dando uma palestra pro pessoal de medicina em Petrópolis na faculdade de lá, dei uma entrevista para o programa deles. Faço a minha militância da 
maneira que as pessoas conhecem vou fazendo. Tenho uma página minha, pessoal, que eu divulgo não só os meus trabalhos como pessoal, mas algumas questões. Faço minha militância virtual.

Gal: Eu acho que o simples fato da gente existir e contar a nossa história para as pessoas já é um ato de militância, já que agente esta levando essa história de nós trans para as pessoas, para elas entenderem um pouco mais sobre pessoas trans. (...). Eu acho que eu trago sim para a faculdade, eu levo para qualquer lugar que vou ser uma transexual sempre vai ser algum assunto quando eu conhecer as pessoas. Em algum momento o assunto vai ser levantado e as pessoas vão fazer questionamentos, algumas perguntas, então sim, e todo espaço que eu vou eu vou fazendo uma militância e tentando conscientizar as pessoas sobre a minha existência como pessoa trans. Eu falo pra elas, "vocês não estão conhecendo todas as pessoas trans, você está conhecendo a Letícia trans, eu estou dizendo para vocês quem sou eu Gal trans, não posso dizer para vocês que todas as pessoas trans vão concordar comigo, somos singulares apesar de estar dentro do mesmo segmento.

Baby: Eu já participei, me chamaram para a mesa, para falar sobre questões trans. Eu não falei em primeira pessoa, falei em terceira pessoa porque eu não gosto de dar ousadia para Zé povinho, porque adolescente é foda. Mas eu falei sobre questões de cisgeneridade, da questão de que transfobia não é só praticada por pessoas cis, hetero. Homossexuais muitas vezes praticam também, de maneira mais pesada, ou se acham mais na liberdade de ser trans friendly, porque colocam a sigla LGBT ou homofobia como um termo guarda-chuva, que não tem nada a ver. Mesmo porque os $L G B$ são relacionados à sexualidade e o Té sobre identidade, né. Mas diretamente mesmo, na faculdade, não. Foi só dessa palestra que eu participei, nunca me chamaram para nenhuma outra, mas se me chamarem eu até iria, dependendo de como fosse.

As atividades de militância no contexto universitário surgem como um imperativo na construção das políticas inclusivas para esse segmento, uma vez que permitem a transição de uma política feita "pelo/a" outro/a” em uma política construída “com” o/a outro/a. Participarem efetivamente neste processo é essencial para a construção de ações que ampliem a visibilidade e debates sobre questões relacionadas à população LGB e, principalmente, T. Nesse sentido, Cazuza narra as conquistas realizadas em seu campus:

Cazuza: Então, a gente tem uma diretoria LGBT agora, que existe há mais ou menos um ano na Universidade Federal, que é um órgão da reitoria, que tem a intenção em desenvolver uma política, que esta dentro de um plano, um projeto, digamos assim. Tem ações de proteção para ajudar na permanência dos estudantes LGBT, que tiverem sofrendo preconceito, como vamos lidar com casos assim, como vamos cuidar disso e construir com os alunos e com os D. As. esse regimento ético, como vamos construir mecanismos contra o preconceito. Enquanto não tiver um regimento ético, uma norma, não temos como fazer nada (...). Vamos ter linhas de pesquisa para poder financiar pesquisas, teremos dinheiro para publicações de livros, um prêmio de estudos LGBT.

É notória a necessidade de um diálogo constante com as demandas do movimento social organizado dentro do contexto universitário entre as/os gestoras/es e docentes no que diz respeito às ações coletivas e às políticas públicas. Essa diretoria LGBT, citada por Cazuza, está sendo implementada por meio de um projeto pioneiro em uma instituição pública, com o objetivo é favorecer o acolhimento, a inserção e a permanência dessa comunidade na universidade. O projeto prevê ações afirmativas objetivando minimizar as desigualdades regionais e sociais, a redução das taxas de retenção e evasão escolar das pessoas travestis, transexuais, transgêneros e intersexuais e, alem disso, promover a inclusão social pela educação universitária.

O documento prevê ainda a promoção de ações protetivas direcionadas à saúde dessa população e voltadas à pesquisa LGBT. (...) Isso é uma ação importante da instituição no sentido de acolhimento a uma população que é cultural e historicamente marginalizada. Ela se insere no contexto mais amplo de 
uma política federal de acolhimento e afirmação da população LGBT que tem dimensões preventivas, nas áreas de proteção dessas pessoas e de acolhimento também. (LIMA, 2016).

$\mathrm{Na}$ visão de Nara, a militância trans e o movimento transfeminista, ao trazerem à tona temas desconhecidos pela grande maioria das pessoas, contribuem para a constituição de uma visibilidade e para a incorporação da necessidade de colocar em discussão as existências trans:

Nara: A partir do momento que eu estava dentro do movimento de militância, já estava vendo que tinha pessoas trans ao meu redor, fazendo respeitar no espaço universitário, na medida que eu ia vendo as pessoas trans conseguindo orquestrar nas redes sociais um movimento que começava a despontar de forma muito conseqüente e impactante a opinião pública.

Para Baby, da mesma maneira que há sistema de cotas para a população negra e indígena, que passaram e continuam passando por processos de exclusão sócio-econômica geradas pelo preconceito historicamente constituído, impossibilitando o acesso e ampliação de seus estudos, também deveria haver cotas para as pessoas transexuais e travestis como incentivo e democratização de igualdade de direitos perante a exclusão.

Ao ser questionada sobre o fato da relação entre a inserção na universidade e uma possível maior "respeitabilidade" e aceitação social, Cássia responde:

Cássia: Com certeza, não só a sociedade, como o próprio meio LGBT, eu consegui uma pequena notoriedade por causa do [programa de TV que participou], na época que fui produtora e eu ter entrado na faculdade virou matéria de site, principalmente com a carteirinha com o nome social. A partir da divulgação dessa matéria, veio muito gente me cumprimentar, "Ai que bom você me representa, quem dera todas fizessem igual a você, é isso mesmo". A gente ainda vive numa sociedade que prioriza e legitima muito um canudo, um papel, um certificado, e no fato de uma travesti, uma transexual conseguir essa inclusão $e$ chegar até o final e manter. (...) Porque ainda tem isso, as pessoas acham que você não vai ficar, que não vai dar conta, então ainda tem essa coisa de ascensão social, você ser vista com outros olhos porque esta fazendo uma faculdade e estereotipar 'ela é diferente as outras porque esta fazendo uma faculdade, infelizmente tem isso sim!'

Gal problematiza, no entanto, a relação comumente estabelecida entre "ter um diploma" e ser mais respeitada:

\begin{abstract}
Acho que sim, não só como pessoas trans, como com todo mundo, né. A gente vê que quem é respeitado é quem esta seguindo o que se deve fazer, então você deve trabalhar, deve estudar, se você seguindo isso direito você deve ser respeitado. Então para as pessoas trans também, eu ouvi até há pouco tempo, "ela é travesti, mas ela estuda, está na faculdade, ela trabalha num trabalho formal pelo menos". (...) E aquelas que dizem que é travesti o tapa na cara que você dá na sociedade é que você esta numa faculdade, vai arranjar um bom, não é esse o tapa na cara que eu quero dar na sociedade, eu quero mostrar que mesmo as trans que estão lá se prostituindo, as pessoas em situação de rua, independente de serem trans ou cis, elas também têm que ser respeitadas. Eu não quero ser uma trans respeitada só porque eu estou dentro apesar e saber que as pessoas vão respeitar mais, se alguma pessoa com estudo e com um bom emprego.
\end{abstract}

Mesmo tendo certa aceitação por já ser uma militante reconhecida e ter publicações com seu nome, Nara ainda não sente segurança por ter um diploma e, posteriormente, adquirir o título de doutora sendo trans:

Eu acho que eu tenho conseguido brechas na sociedade para ter retorno financeiro, ter alguma expectativa de reconhecimento ainda dentro desse ponto de vista de uma figura exótica da pessoa trans, que é eloqüente da pessoa trans que consegue ocupar o espaço público e falar coisas que tiram as pessoas do seu lugar de conforto, não sei o quanto uma universidade vai permitir me contratar como professora, por ex. fico na dúvida, mesmo se isso é possível mesmo com um diploma de doutora pela universidade. Vou testar isso no ano que vem! Tenho um pouco de receio do quanto isso seria viável. 
Esse medo de não aceitação, que aparece na fala de Nara, é muito frequente para a pessoa transexual ou travesti, por não ser enquadrada dentro de modelo cisheteronormativo construído. Ao narrar, em sua tese, seu período de acesso e permanência no contexto universitário desde a graduação até seu doutoramento, Luma Andrade (2012) também descreve, como todas/o interlocutoras/r desta pesquisa, situações vexatórias e excludentes que sua travestilidade lhe causava. Entre tantas situações de exclusão, particularmente sua presença no doutorado do programa de pós-graduação em Educação na Universidade Federal do Ceará, merece destaque:

Iniciei o curso de Doutorado e me deparei com situações que jamais pensei encontrar, como colegas que mudavam a fisionomia facial ao me verem em sala e durante algumas aulas questionavam minha sexualidade. Outro fato que me indignava era a forma como alguns professores, ao serem procurados pela imprensa para falar sobre o que achavam de uma travesti fazendo Doutorado, respondiam que era normal, que não viam nada de excepcional nisso. Normal? Comum? Essas observações me deixavam perplexa, pois eles tentavam passar algo que só existe na teoria como sendo uma prática real, quando na verdade é completamente diferente; se fosse tão simples, eu não teria sido a primeira travesti do Brasil a cursar um Doutorado, outras estariam nas academias, mas poucas travestis sequer chegam a concluir o Ensino Fundamental e Médio, segundo a Associação Nacional das Travestis (ANTRA). (ANDRADE, 2012, p. 86).

Segundo a autora, não há dúvidas de que sua aprovação no doutorado lhe conferiu mais respeito e aceitação, mas alega que, ainda, no presente momento, a população travesti e transexual vem sendo, na maioria das vezes, tolerada com muitas restrições tanto nas escolas, quanto em universidades.

Segundo Elza, cursar o ensino superior possibilita até mesmo mais respeito na abordagem policial:

A questão da faculdade confere a isso. Já é alguma coisa, o tratamento é diferenciado. Na própria abordagem, só o fato de você citar que você é estudante, seja lá de que faculdade for, já parece que o policial já começa... ele já bota um pé atrás. Você já percebe isso. Você percebe porque eu posso fazer essa mensuração porque eu já fui abordada em momentos que eu não estava estudando e agora, você entendeu? E eu percebi que existe essa diferença. Tudo muda, entendeu? Você tem um grau superior. O próprio nome já diz, não é? Você é superior. Tem gente que até exagera, né? Já "Ai, eu sou superior a você porque eu tenho uma faculdade, ou estou fazendo uma faculdade”. Porque culturalmente existe uma elitização disso, né, do indivíduo que faz faculdade. Eu acho que não deveria ser assim. Eu não gosto disso, para falar a verdade.

Baby já questiona que, para ser aceita em sua singularidade, ainda que tenha ensino superior, é necessário enquadrar-se dentro do modelo cisheteronormativo.

Baby: Então, a ascensão social, eu não acredito em meritocracia. Não acredito que isso vai acontecer, mas abre portas. Porque eu tenho um adicional a mais para colocar no meu currículo, uma área específica para procurar, e a questão do preconceito sempre vai existir em todos os âmbitos, mas é um fator higienizante. Porque é isso que a sociedade quer que as pessoas trans façam, se higienizem. As mulheres sejam mais femininas, os homens sejam mais masculinos, retifiquem os documentos e, de preferência, não toquem no assunto, porque ninguém quer entender que existem pessoas que nascem com genital divergente do que é tido como feminino ou masculino, e se reconheça ou pertença, no caso, ao gênero que não coincide com esse genital que é tido como masculino ou feminino. Mas eu acho que a questão do estigma são estigmas, como a prostituição. As pessoas pensam em travesti, já pensam em roubo, em prostituição, em barraco, em vulgaridade. Eu acho que é um estigma que você vai ajudar a dar uma quebrada. As pessoas falam "olha, ela é transexual”, pode vir aquele clichê do "não parece", mas que está estudando, está trabalhando. Já é uma coisa que ajuda a te afastar do julgamento mesmo.

Torna-se necessário reconhecer que o acesso à educação superior em nosso país transformou-se em objeto de disputa política, pois confronta, segundo CATANI et al. (2002), de um lado, perspectivas mais elitistas de limitar o acesso e de manutenção do prestígio dos diplomas para poucos e, de outro, 
perspectivas mais populares de ampliação do acesso representando desejos de outras camadas da sociedade, cujos objetivos são a inserção profissional e a ascensão social das mesmas.

As falas das/o entrevistadas/o apontam para a necessidade de ampliação do acesso e permanência de populações trans dentro do contexto universitário com o maior reconhecimento das demandas pelos direitos de travestis e transexuais, alterando o olhar da sociedade cisheteronormativa, voltado às transexualidades, em direção a uma sociedade mais inclusiva e aberta para a diversidade. Um desses dilemas, o referente ao acesso e permanência de pessoas trans, é explicitado por Nara:

O instituto que eu estou, as humanas na [Universidade Estadual] estão ainda mais vendo como um fascínio
as figuras trans empoderadas chegando e ocupando um espaço, estão fascinadas, abismadas, pasmas com o
fato da gente chegar e se colocar nesses lugares de forma tão senhoras de si, sabe! Acredito que por
enquanto está mais tranqüilo, nesses institutos ali [Ciências humanas e artes], agora o restante da
Universidade ainda vê com desprezo muito nitido essas figuras trans, a questão LGBT como um todo, não só
a trans, mas em especial, tenho amigas que estão fazendo engenharia da computação e estão passando
maior perrengue e mesmo no Instituto de Ciências Humanas, tem um aluno, homem trans que passou
bastante perrengue, a questão dele que ele foi um dos primeiros, já tinha tido a [mulher trans] que fazia
mestrado e durante o mestrado se assumiu trans.

Quando questionadas/o sobre o que pensam de suas vidas futuramente, ou seja, o que almejam conquistar com um curso universitário, os projetos futuros das/do participantes, alternam desejos comuns de ascensão pessoal com reflexões acerca da importância da visibilidade trans em ocupações que exigem maior escolaridade.

Acreditando nessa possível expansão do acesso e permanência de populações transexuais no contexto universitário, tem-se em mente que ações afirmativas contribuíram na democratização dos processos educacionais em nosso país. Entretanto, quando refletimos sobre as populações trans, ainda existem inúmeras barreiras em relação a políticas públicas que precisam ser discutidas e problematizadas em todos os meios. Observa-se que é necessário e importante que as histórias, memórias e vozes dessas populações invisíveis, e/ou outras, sejam ouvidas para que fomentem políticas públicas participativas, visando oferecer garantias e soluções coletivas que transformem suas realidades.

\section{Considerações finais}

As várias situações que fundamentam separações entre gêneros, estimulando a competição e, em seguida, a perpetuação de preconceitos generificados, contribuíram para que situações de discriminação fossem comuns em suas vidas, inclusive no período escolar, onde foram recorrentes os relatos acerca da ausência de conhecimento das/os docentes, das/os gestores e das/os funcionários das escolas com relação a questões relacionadas às diversidades sexual e de gênero, gerando, consequentemente, invisibilidade e preconceito quando se coloca em pauta, no ambiente escolar, esses corpos que não condizem com a cisheteronormatividade.

A possibilidade da ascensão social pela via de um "bom emprego" (que supostamente exige qualificação) é barrada pela transfobia no mercado formal de trabalho. Isso as levou à exploração excessiva dos empregos precários, ou à necessidade, muitas vezes, de se prostituírem. A precariedade de 
empregos ofertados a travestis e transexuais no mercado de trabalho são consequências da opressão de gênero, abjeção ao diferente e não-aceitação das expressões de gênero trans.

No entanto, por meio das conquistas do movimento trans e de outros movimentos, as/o interlocutoras/r puderam ingressar em seus cursos universitários buscando, pela via da qualificação universitária, o reconhecimento humano e a aceitação de ser respeitadas/o enquanto futuras/o profissionais. Entre essas conquistas, destacam-se: a implementação legal e o direito de utilização do nome social para travestis e transexuais em instituições de ensino que aderiram à legislação e nas avaliações nacionais como o ENEM; as políticas de inclusão governamentais ao acesso a minorias étnicas e raciais de baixa renda, pelo oferecimento de vagas em universidades públicas federais e estaduais, pelo sistema SISU; e o oferecimento de bolsas de estudos em universidades privadas e confessionais, pelo PROUNI.

Podemos também citar como fundamentais para este acesso, os projetos sociais que vêm ampliando o acesso de travestis e transexuais nas universidades em todo país. Contudo, um ponto relevante evidenciado na presente pesquisa é o de que ainda são isolados os casos de políticas públicas de permanência quando se relaciona à população trans. Em geral, os auxílios aos participantes da pesquisa ocorreram somente se estavam na situação de cotistas por renda, ou seja, não há uma especificidade no oferecimento e manutenção de políticas públicas que contribuam para sua permanência.

$\mathrm{O}$ direito à educação de qualidade é um aspecto fundamental e deve ter como prioridade a construção de uma sociedade inclusiva e, por isso, assegurar adequadamente esse direito é um dever do Estado. Desta maneira, acredita-se que as políticas de democratização do ensino requerem não apenas oferecer condições para que todos e todas possam estudar, mas também assegurar a igualdade de oportunidades, inclusive do ponto de vista qualitativo. No caso das/o transexuais pesquisadas/o, as dificuldades encontradas incluem: pagar a matrícula da universidade (no caso das universidades particulares e/ou confessionais); a utilização de banheiro segundo o gênero de identificação; o acesso à moradia estudantil; bolsas de auxílio alimentação; trato adequado por parte de docentes e funcionárias/os não capacitadas/os a lidarem com o tema.

Os relatos sobre preconceito dentro do contexto universitário são menos incisivos dos que os existentes nas escolarizações fundamental e média, porém existem, e ambos estão relacionados, uma vez que as/o interlocutoras/ $\mathrm{r}$ evidenciaram o medo de que a universidade reproduzisse os mesmos preconceitos e exclusões que sentiram na fase escolar. A necessidade de sobrevivência dentro de um universo que ainda não as/o compreende e o sentimento de isolamento no contexto universitário frente à transexualidade também são elementos que foram apontados como problemáticos.

Além das conquistas sociais obtidas em uma esfera macro, não há dúvidas de que a militância trans emergente no contexto universitário de uns anos para cá - e efetivamente exercida pelas/o interlocutoras/r nos espaços universitários - apresentou-se como importante para a transformação do 
ambiente que habitam, contribuindo para a mudança de paradigmas, para a aceitação de suas subjetividades, o reconhecimento de direitos e o respeito às diversidades humana e de gênero.

Segundo elas/e, não basta só proporcionar qualificação intelectual. A Universidade tem o dever social de criar e oferecer políticas de manutenção das existências trans, pois a realização de um curso universitário pode proporcionar, para esse segmento, maior aceitação por parte da família e pela sociedade, como um todo.

Os resultados obtidos apontam que, por mais que as ações afirmativas e as políticas públicas voltadas para populações travestis e transexuais ainda sejam insuficientes, muitas de suas conquistas são fruto da militância e de organizações não-governamentais voltadas para esses segmentos.

\section{Notas}

${ }^{1}$ Neste artigo, será utilizada a noção de "pessoas trans", categoria que aglutina as identidades tanto "travesti" quanto "transexual". Para CARRARA e CARVALHO (2013), a unificação do termo serve para obtenção de um reconhecimento e fortalecimento do grupo no cenário político.

${ }^{2} \mathrm{O}$ termo 'queer' segundo BUTLER (2012) tem sido usado, na literatura anglo-saxônica, para abranger as terminologias 'gay' e 'lésbica'. Tem sido empregado, historicamente, para se referir de forma depreciativa às pessoas homossexuais. Sua utilização pelos ativistas dos movimentos homossexuais constitui uma tentativa de recuperação da palavra, revertendo sua conotação negativa original. Essa utilização renovada da palavra joga também com um de seus outros significados, o de 'estranho'. Os movimentos homossexuais falam, assim, de uma política queer, ou de uma teoria queer.

${ }^{3}$ Segundo o relatório TRANSRESPECT VERSUS TRANSPHOBIA WORLDWIDE (2012), a transfobia é um conjunto de formas de violência, discriminação, ódio, desgosto, comportamento agressivo e atitudes negativas direcionadas a indivíduos ou grupos que transgridem ou que não estão em conforme com as expectativas e normas sociais em torno do gênero. Isto inclui formas institucionalizadas de discriminação, criminalização, patologização e estigmatização e a manifestação em vários caminhos, variando de violência física, discurso de ódio, insulto e meios de comunicação hostis para formas de opressão e exclusão social. A transfobia afeta, particularmente, gênero variante e pessoas trans. (p.18).

${ }^{4} \mathrm{Na}$ gestão atual da prefeitura de São Paulo gerida por João Dória (PSDB), houve um corte do número de bolsas pela metade. Segundo entrevista cedida a militantes de grupos LGBTs, o coordenador de políticas públicas LGBT da prefeitura alega era de que "[...] programa prezaria pela qualidade, não pela quantidade". (DOLCE, 2017).

${ }^{5}$ As únicas iniciativas encontradas foram relativas ao direito do uso do nome social que foi regulamentado em algumas universidades públicas, como é o caso da UFSCar, UFSC, UESPi, UFPE, UFPR, UFS, UNB, UFA, UFP, UFES, etc.

${ }^{6}$ São utilizados nomes fictícios para apresentar as/o interlocutoras/r e suas trajetórias de vida, objetivando facilitar o acesso às suas histórias e experiências. Foi apresentado ao início das entrevistas um "Termo de Consentimento Livre e Esclarecido", como instrumento acordado entre o pesquisador e as/o participantes, que os dados construídos na entrevista iriam utilizados na pesquisa e que a entrevista foi concedida com fins estritamente de pesquisa, inclusive para sua possível publicação. Na descrição, serão omitidos nomes de pessoas e/ou instituições que possam levar à identificação das/o participantes. As identidades de gênero e étnico-raciais são autodeclaradas.

${ }^{7}$ Conceito formulado por Judith Butler na obra Gender Trouble (1990), e discutido por LEITE JR (2012): "pode-se afirmar que o abjeto é o ininteligível, aquilo que, na constituição do sujeito (individual ou social), é expulso como não categorizável” (LEITE JR, 2012, p.560). O abjeto é o que está fora das categorias de pensamento socialmente inteligíveis. Nesse sentido, abjeto é uma categoria de linguagem que denomina a falta de categorias de pensamento, ou seja, aquilo que fica de fora, expulso das categorias de pensamento socialmente criadas, estabelecidas e culturalmente inteligíveis em determinado período histórico.

${ }^{8}$ Segundo MATTOS e CIDADE (2016), desde o século XX, alguns campos mais conservadores da psicologia têm se consolidado como ár eas cientificas que explicam, diagnosticam e cuidam de corpos considerados não condizentes pelas normas estabelecidas socialmente. "Consagrando-se assim, como campo originário na formação dos discursos no que diz respeito às questões de gênero e sexualidade, tornando-se (...) um campo especialmente prolífico na produção de conceitos, categorias e teorias que promoveram uma naturalização do elo entre determinado genital, sexo, gênero e orientação sexual. Tal naturalização, fundada sobre preceitos evolucionistas (que ressaltam os fins reprodutivos da dimensão sexual humana), foi nomeada por autoras transfeministas como cisheteronormatividade, identificável em diferentes campos do conhecimento". (MATTOS, CIDADE, 2016. p. 135).

${ }^{9}$ O Projeto de Lei de identidade de Gênero, proposto pelo Deputado Jean Wyllys e a Deputada Érika Kokay (PL 5002/2013), citado por Baby, tem como base oferecer direitos legais e sociais que beneficiem a população travesti e transexual em relação a questões que incluem a legalização da identidade de gênero com base na identificação pessoal, o reconhecimento do nome social, o acesso a medicamento no processo de transição corporal, a hormonização, e a cirurgia de transgenitalização, dentre outras questões.

${ }^{10}$ Segundo ALMEIDA (2012), o cenário político no período pós 1988, a democracia deixa de ser uma ideia subjacente para se tornar a ideia-força organizadora da representação. Neste processo, o sistema político passou por um movimento intenso de inovação institucional - fundamentado pela promulgação de nova Constituição e mudanças na legislação ordinária - marcado pela pluralização do sistema partidário; democratização do sistema eleitoral; reorganização político administrativa do país, na inclusão do município como parte integrante e autônoma da Federação; ampliação das responsabilidades do Estado no provimento de direitos sociais e criação de canais variados de interação com a sociedade e expressão da soberania popular. Como se pode perceber, as mudanças não ficaram restritas à dimensão eleitoral e estatal da representação, mas atingiram a esfera de atuação da socie dade civil. Desse modo, ocorre um processo de descentramento da representação política no Brasil, que terá impacto tanto na forma centralizada do Estado pensar a organização do país, quanto nos atores que são protagonistas e partícipes da política. (ALMEIDA, 2012).

${ }^{11}$ A passabilidade para DUQUE (2017) faz parte das estratégias discursivas onde as performances de gênero podem se aproximar do que se acredita ser uma pessoa cisgênera. Para o autor, "aproximar-se dos normais, isto é, daqueles mais inteligíveis - ser identificado como um homem e uma mulher de 'verdade', em termos também de classe, raça/cor e idade mais privilegiados - é uma forma de se proteger, mas diferenciar-se dos normais e dos tidos com experiências mais coerentes com as convenções hegemônicas, inclusive alçando a categoria de corajosamente diferente, é outra forma de fazê-lo". Tanto uma como a outra estão mutuamente se constituindo enquanto possibilidades de sobrevivência viável em um contexto ainda pouco acolhedor dos "mais diferentes". (DUQUE, 2017. p. 503) 


\section{Referências}

ALMEIDA, Débora Resende. O conceito de representação política no Brasil: quatro momentos de continuidades e inovações. In: Anais do $8^{\circ}$ Encontro da Associação Brasileira de Ciência Política. Gramado, 2012. Disponível em: https://cienciapolitica.org.br/system/files/documentos/eventos/2017/02/conceitoquatro-momentos.pdf. Acesso em 2 de novembro de 2019.

ALMEIDA, Wilson de Mesquita. O Prouni e a "Democratização do Ensino Superior": Explorações Empíricas e Conceituais. In: Anais da $33^{a}$ Reunião Nacional da Anped, Florianópolis, 2010. Disponível em: http://33reuniao.anped.org.br/33encontro/app/webroot/files/file/Trabalhos\%20em\%20PDF/GT11-6232--Int.pdf.

Acesso em: 22 de maio de 2018.

ANDRADE, Luma Nogueira de. Travestis na escola: assujeitamento e resistência à ordem normativa. 2012. 278 fs. Tese (Doutorado em Educação) - Universidade Federal do Ceará, Fortaleza, 2012.

BOECKEL, Cristina L. 2016. Casa ajuda transexuais e travestis a conquistar educação e respeito. 2016. Disponível em: http:/g1.globo.com/rio-de-janeiro/noticia/2016/07/casa-na-lapa-ajuda-transexuais-e-travestis-conquistar-educacaoe-respeito.html. Acesso em 22 de maio de 2018.

BUTLER, Judith. Problemas de Gênero. Feminismo e subversão da identidade. Rio de Janeiro: Civilização Brasileira, 2012.

CARVALHO, M.; CARRARA, S. Em direção a um futuro trans? Contribuições para a história do movimento de travestis e transexuais no Brasil. Revista Latino Americana: Sexualidad, Salud y Sociedad, n. 14, pp.319-351, 2013.

CARVALHO, Mirela. Exclusão de gênero do Plano Nacional de Educação é retrocesso, diz educador. 2015. Disponível em: $\mathrm{http} / /$ ultimosegundo.ig.com.br/educacao/2015-12-26/exclusao-de-genero-do-plano-nacional-de-educacao-eretrocesso-diz-educador.html. Acesso em 22 de maio de 2018.

CATANI, Afrânio Mendes. OLIVEIRA, João Ferreira de. DOURADO, Luiz Fernandes. A política de avaliação da educação superior no Brasil em questão. In: DIAS SOBRINHO, José. RISTOFF, Dilvo. (Orgs.). Avaliação democrática - para uma universidade cidadã. Florianópolis: Insular, 2002, p 99-118.

DIAS SOBRINHO, José. Democratização, qualidade e crise da educação superior: Faces da exclusão e limites de inclusão. Revista Educação e Sociedade, v. 31, nº 113, p. 1223-1245, 2010.

DIAS SOBRINHO, José. Educação Superior: Bem Pública Equidade e Democratização. Revista Avaliação, v. 18, n. 1, p. 107-126, 2013.

DOLCE, Júlia. 2017. Ativistas denunciam corte em programas destinados a pessoas trans na gestão Dória.2017. Disponível em: https://www.brasildefato.com.br/2017/06/28/ativistas-denunciam-corte-em-programas-destinadosa-pessoas-trans-na-gestao-doria/. Acesso em 30 de maio de 2018.

DUQUE. Tiago. "É mais fácil para as mais bonitas": corpo, imagem e reconhecimento nas experiências de (não) passar por homem e/ou mulher. Revista Contemporânea, v.7, nº 2, p. 483-504, 2017.

FACCHINI, Regina; FRANÇA, Isadora Lins; VENTURI, Gustavo. Sexualidade, cidadania e homofobia: pesquisa $10^{a}$ Parada do Orgulho GLBT de São Paulo - 2006. São Paulo: APOGLBT, 2007.

GARCIA, M. R. V. "Homofobia e Heterossexismo nas escolas: discussão da produção científica no Brasil e no mundo". Anais do IX Congresso Nacional de Psicologia Escolar e Educacional, São Paulo, 2009. Disponível em: http://nepaids.vitis.uspnet.usp.br/wp-content/uploads/2010/04/13.pdf Acesso em 22 de maio de 2018.

GONÇALVES, Gean Oliveira. Narrativas Queer no Jornalismo: o desafio da complexidade e das compreensões sobre gêneros e sexualidades. Anais do XXXVIII Congresso Brasileiro de Ciências da Comunicação. Rio de Janeiro, 2015. Disponível em: http://portalintercom.org.br/anais/nacional2015/resumos/R10-0754-1.pdf. Acesso em 22 de maio de 2018.

INEP. Mais de 400 travestis e transexuais usarão nome social no Enem 2016. Disponível em http://www.brasil.gov.br/educacao/2016/07/mais-de-400-travestis-e-transexuais-usarao-nome-social-no-enem2016. Acesso em 22 de maio de 2018. 
IRIGARAY, Hélio Arthur Reis. Identidades Sexuais Não-Hegemônicas: A Inserção dos Travestis e Transexuais no Mundo do Trabalho Sob a Ótica Queer. In: Anais ANPAD, Florianópolis, 2010. Disponível em: http://www.anpad.org.br/admin/pdf/eneo425.pdf. Acesso em 22 de maio de 2018.

JESUS, Jaqueline, G. Interlocuções Teóricas do pensamento transfeminista. In: JESUS, Jaqueline G et al., Transfeminismo: teoria e prática. Rio de Janeiro: Metanóia, 2015. p. 17-32.

LEITE JUNIOR, Jorge. Transitar para onde? Monstruosidade, (Des) patologização, (In) segurança social e identidades transgêneras. Revista Estudos Feministas, Florianópolis. Vol 20, nº 2, maio/agosto, /2012. p.559-568.

LIMA, Anderson. 2016. Universidade Federal de Pernambuco lança Política LGBT. Disponível em: http://www3.ufpe.br/sib/index.php?option=com_content\&view=article\&id=459:universidade-federal-depernambuco-lanca-politica-lgbt\&catid=6\&Itemid=122. Acesso em 22 de maio de 2018 .

LOURO, Guacira Lopes. Gênero, sexualidade e educação. Uma perspectiva pós-estruturalista. Petrópolis, RJ: Vozes, 1997.

MATTOS, Amana; CIDADE, Maria Luiza Rovaris. Para pensar a cisheteronormatividade na Psicologia. Periódicus. Salvador. Vol. 1, nº. 5, maio/outubro, 2016. p.132-153.

MISKOLCI, Richard. A Teoria Queer e a Sociologia: o desafio de uma analítica da normalização. Revista Sociologias, Porto Alegre. Ano 11, nº 21, Janeiro/Junho, 2009, p. 150-182.

PETERS, Michael. Pós-estruturalismo e filosofia da diferença. Tradução: Thomas Tadeu da Silva. Belo Horizonte: Ed. Autêntica, 2000.

QUEIRÓZ, Maria Isaura Pereira de. Variações sobre técnica de gravador no registro da informação viva. São Paulo: CERU, 1983.

RONDAS, Lincoln de Oliveira; MACHADO, Lucília Regina de Souza. Inserção profissional de travestis no mundo do trabalho: das estratégias pessoais às políticas de inclusão. Pesquisas e Práticas Psicossociais, v. 10, n. 1, p. 194207, 2015.

TRANSRESPECT VERSUS TRANSPHOBIA WORLDWIDE. Disponível em: https://transrespect.org/ Acessado em: 28 de novembro de 2019.

TONELI, Maria Juracy Filgueiras. BONASSI, Bruna Camillo. AMARAL, Marília dos Santos. QUEIROZ, Mariana Amaral de. Vulnerabilidades mapeadas, Violências localizadas: Experiências de pessoas travestis e transexuais no Brasil. Quaderns de Psicologia, v. 17, n. 3, p. 83-98, 2015.

Informação sobre os revisores de línguas

Língua Portuguesa

Língua Inglesa

Língua Espanhola
Cláudia Megale Adametes Braga

E-mail: letra.assessoria@gmail.com

Amana Rocha Mattos

E-mail: amanamattos@gmail.com

Karina Marques da Silva

E-mail: Karcap2@gmail.com 